\title{
Seasonal variations in vertical migration of glacier lanternfish, Benthosema glaciale
}

\author{
Eivind Dypvik · Anders Røstad $\cdot$ Stein Kaartvedt
}

Received: 8 February 2012/ Accepted: 30 April 2012/Published online: 5 June 2012

(C) The Author(s) 2012. This article is published with open access at Springerlink.com

\begin{abstract}
The seasonal variations in glacier lanternfish (Benthosema glaciale) vertical distribution and diel vertical migration (DVM) were studied by use of a bottom-mounted upward-facing $38 \mathrm{kHz}$ echo sounder deployed at $392 \mathrm{~m}$ depth and cabled to shore in Masfjorden $\left(\sim 60^{\circ} 52^{\prime} \mathrm{N}\right.$, $\sim 5^{\circ} 24^{\prime} \mathrm{E}$ ), Norway. Acoustic data from July $2007-$ October 2008 were analyzed, and scattering layers below $\sim 220 \mathrm{~m}$ during daytime were attributed to glacier lanternfish based on net sampling in this, and previous studies, as well as from analysis of the acoustic data. At these depths, three different diel behavioral strategies were apparent: normal diel vertical migration (NDVM), inverse DVM (IDVM), and no DVM (NoDVM). NoDVM was present all year, while IDVM was present in autumn and winter, and NDVM was present during spring and summer. The seasonal differences in DVM behavior seem to correlate with previously established seasonal distribution of prey. We hypothesize that in regions with seasonally migrating zooplankton, such as where calanoid copepods overwinter at depth, similar plasticity in DVM behavior might occur in other populations of lanternfishes.
\end{abstract}

Communicated by S. A. Poulet.

E. Dypvik $(\bowtie) \cdot$ A. Røstad $\cdot$ S. Kaartvedt

Red Sea Research Center, 4700 King Abdullah University of Science and Technology, Thuwal 23955-6900, Saudi Arabia e-mail: eivind.dypvik@kaust.edu.sa

A. Røstad

e-mail: anders.rostad@kaust.edu.sa

S. Kaartvedt

e-mail: stein.kaartvedt@kaust.edu.sa

\section{Introduction}

Myctophids (Myctophidae) are mesopelagic fishes distributed in all the world's oceans (Dalpadado and Gjøsæter 1988; Cherel et al. 2010), playing an important role in the marine ecosystems (Gjøsæter and Kawaguchi 1980; Cherel et al. 2010) as trophic links between zooplankton (Kinzer and Schulz 1985; Shreeve et al. 2009) and piscivorous predators (Giske et al. 1990; Markaida and Sosa-Nishizaki 2003; Doksæter et al. 2008; Hedd et al. 2009). They are also likely to play a major role in the vertical flux of organic matter from the upper productive layer to deeper layers (Radchenko 2007; Hernandez-Leon et al. 2010). Their vertical distribution and diel vertical migration behavior affect such interactions and processes, making it important to reveal these patterns. The myctophid glacier lanternfish (Benthosema glaciale) and the sternoptychidae pearlside (Maurolicus muelleri) are the dominant mesopelagic fish in Norwegian fjords (Aksnes et al. 2004; Kristoffersen and Salvanes 2009). In Masfjorden, pearlside dominates acoustic scattering layers (SL's) shallower than $200 \mathrm{~m}$, while glacier lanternfish dominates the SL's below 200-250 m (Giske et al. 1990; Bagøien et al. 2001; Kaartvedt et al. 2009; Dypvik et al. 2012).

Diel vertical migration (DVM) is commonly referred to as a trade-off between feeding opportunities and predation risk induced by changes in light intensity (Clark and Levy 1988; Pearre 2003; Cohen and Forward 2009; Ringelberg 2010). Thus, light is the proximate cause of DVM influencing the time of migration and vertical extent of migration (Ringelberg and Van Gool 2003; Staby and Aksnes 2011), while the distribution of food and predation risk are regarded as major drivers for fish vertical distribution and migration (Clark and Levy 1988; Bailey 1989; Neilson and Perry 1990; Sutton and Hopkins 1996). 
However, size (Busch and Mehner 2012), internal factors such as energy reserves (Hays et al. 2001) and hunger (Pearre 2003), and external factors such as currents (Bennett et al. 2002) and temperature (Wurtsbaugh and Neverman 1988; Sogard and Olla 1996; Mehner et al. 2010) may also influence vertical distribution and migration. In normal DVM (NDVM), individuals ascend toward the surface at night before descending to deeper waters during the day. In the less common inverse DVM (IDVM), individuals ascend in the water column at daytime and descend during the night (Pearre 2003).

Glacier lanternfish is known to carry out NDVM (Halliday 1970; Roe and Badcock 1984; Sameoto 1988), IDVM (Kaartvedt et al. 2009; Dypvik et al. 2012) or display no diel vertical migration (NoDVM) (Roe and Badcock 1984; Albikovskaya 1988; Kaartvedt et al. 2009). The depth distribution of myctophids is size dependent with larger fish distributed deeper than smaller individuals (Willis and Pearcy 1980; Gartner et al. 1987; Dypvik et al. 2012). Therefore, differences in conspicuousness (Hays et al. 1994), vision (capabilities) for detecting prey (Warrant and Locket 2004), internal state (satiation and hunger) (Cailliet and Ebeling 1990; Staby et al. 2011), and motivation (Rosland and Giske 1997; Busch and Mehner 2012) are expected to result in a mixture of migration patterns, which may occur simultaneously.

Glacier lanternfish feeds on a variety of zooplankton (Gjøsæter 1973; Roe and Badcock 1984; Sameoto 1988), but seems to prefer calanoid copepods, especially Calanus (Sameoto 1988, 1989; Baliño and Aksnes 1993; Dypvik et al. 2012). The main pattern in seasonal zooplankton abundance and vertical distribution at the site for this study is established from previous studies at the same or adjacent locations. In spring and summer, most zooplankton are distributed in the upper part $(<30 \mathrm{~m})$ of the water column (Rasmussen and Giske 1994). However, during autumn and winter, the highest biomass of zooplankton is below $150 \mathrm{~m}$ (Giske et al. 1990; Baliño and Aksnes 1993; Bagøien et al. 2001). This is because zooplankton vanishes from upper layers as primary production declines, but also because of seasonal vertical migration among the main calanoid copepod species, Calanus spp., which leaves upper waters, descending for "overwintering" in mid-waters (Bagøien et al. 2001). In Norwegian waters, this seasonal descent may begin in summer (Kaartvedt 2000). Myctophids are capable of feeding at mesopelagic depths (Roe and Badcock 1984; Sameoto 1988; Pusch et al. 2004), so that the seasonal migration of Calanus to deep waters may represent an important food source in the daytime habitat of the fish (Dypvik et al. 2012). In Norwegian fjords, glacier lanternfish exercise a strong predation pressure on overwintering Calanus (Bagøien et al. 2001) and can influence their vertical distribution (Kaartvedt 1996).
Mesopelagic fish can be studied by use of echo sounders as they tend to aggregate into SL's (Holton 1969; Godø et al. 2009; Kaartvedt et al. 2009). Normally, acoustic studies of mesopelagic fish are carried out in periods restricted by time or seasonality (Collins et al. 2008; Godø et al. 2009; Kloser et al. 2009), and to our knowledge, there is no systematic study addressing how migration patterns in a population of glacier lanternfish, or other myctophids, may vary throughout a year. However, the use of moored echo sounders can give long-time acoustic data series (Brierley et al. 2006; Doksæter et al. 2009; Staby et al. 2011). Here we take advantage of the unique opportunity for a long-term study offered by a deep fjord where populations of mesopelagic fish are easily accessible. We present data from 16 months of continuous acoustic registrations (July 2007-October 2008), enabling us to address the seasonal patterns of diel vertical behavior, unveiling the relative occurrence and consistency of NDVM, IDVM, and NoDVM by glacier lanternfish.

At the outset of this study, we hypothesized that the patterns of glacier lanternfish DVM would vary seasonally, as recently documented for the pearlside (Staby et al. 2011), likely in relation to the seasonal distribution of prey. Given the general seasonal zooplankton dynamics of Norwegian fjords, we hypothesize that during spring and summer, when the abundance of potential prey is high in near-surface waters, the glacier lanternfish migrate to the upper part of the water column at night (NDVM) to feed, avoiding visual predators in the bright surface waters during daytime. Conversely, we hypothesize that during autumn and winter, when food is sparse in upper waters, and at seasonal high in mid-waters, as seasonally migrating copepods have descended to their overwintering habitat, glacier lanternfish restrain from migrations to the surface at night, rather exploiting the prey in mid-waters by performing IDVM toward favored light conditions in shallower waters during daytime (Dypvik et al. 2012). Furthermore, for the NoDVM layer, we investigate two alternative hypotheses: (1) the population really does split into migrating and non-migrating components (Pearcy et al. 1979) or (2) migrations are undertaken also among the NoDVM component, but not detected by standard methods because they are asynchronous, so that a proportion of the population always is present in deep waters (Sutton and Hopkins 1996; Pearre 2003). Since our approach facilitates studies of individuals, we have the possibility of addressing these competing hypotheses.

\section{Materials and methods}

The study was undertaken in Masfjorden $\left(\sim 60^{\circ} 52^{\prime} \mathrm{N}\right.$, $\sim 5^{\circ} 24^{\prime}$ E), Norway (Fig. 1). For a detailed description of 
Fig. 1 Map depicting location of the bottom-mounted echo sounder (gray circle) at $392 \mathrm{~m}$ depth in Masfjorden, Norway

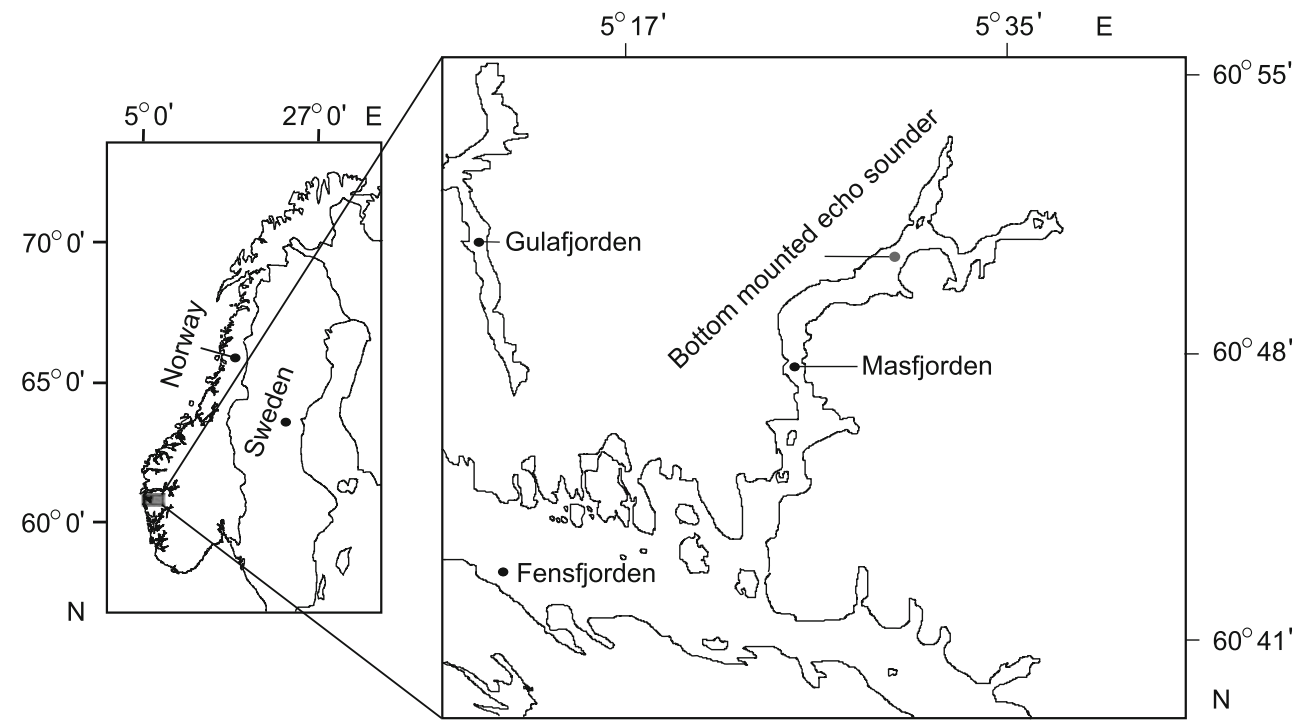

activity in the NoDVM layer, which by definition was expected to have little vertical migration, we randomly picked 1 day for each season (18 October 2007; 2 February; 12 March 2008; 8 August 2008), focusing on the 300-390 m depth interval. For these days, we furthermore selectively chose examples where vertical swimming was seen in the compressed, daily echograms, and portrayed these at higher resolution for better depicting individual behavior.

Abundance estimates to identify the variation in concentration of glacier lanternfish in different depth intervals between day and night were made by echo integration. This was done with day and depth divided into blocks of $1 \mathrm{~h}$ and $10 \mathrm{~m}$ respectively between $\sim 250$ and $390 \mathrm{~m}$ for days where $24 \mathrm{~h}$ of echo data were successfully retrieved (from min. 4 days in Sept. 2007 and Oct. 2008, to max. 24 days in May 2008). Time for sunrise and sunset was set to the 15 th of each corresponding month, as an approximate for each month, determining time allocated to day and night. Glacier lanternfish makes up the main part of the volume backscattering $\left(S_{\mathrm{v}}\right)$ at $-90 \mathrm{~dB}$, while larger fish results in $S_{\mathrm{v}}$ values greater than $-64 \mathrm{~dB}$ (Bagøien et al. 2001). Thus, values retrieved by echo integration at $-64 \mathrm{~dB}$ were subtracted from the echo integration at $-90 \mathrm{~dB}$ to exclude fish larger than glacier lanternfish (Bagøien et al. 2001). The concentrations (individuals $\mathrm{m}^{-3}$ ) were derived from measurements of $S_{\mathrm{v}}$ and target strength (TS, see description below) by dividing the linear $S_{\mathrm{v}}$ values with the linear TS (MacLennan and Simmonds 1992).

TS depends on the size, anatomy, and behavior of the organism, as well as the frequency of the echo sounder (MacLennan and Simmonds 1992). For precise estimation of concentration, the TS of glacier lanternfish was obtained monthly by means of automatic target tracking (TT), performing TT for 3 days of every month within a range of 
10-50 $\mathrm{m}$ from the transducer ( $\sim 340-380 \mathrm{~m}$ depth). This limited range was chosen as the resolution of acoustic data decreases with distance from the transducer, and so does the precision of the TS estimates. Minimum track length was set at 10 ping, maximum ping gap to 1 ping and gating range to $0.3 \mathrm{~m}$ during tracking. TS values between -65 and $-50 \mathrm{~dB}$ were regarded as glacier lanternfish, as TS values stronger than $-50 \mathrm{~dB}$ indicate fish of greater size (Foote 1980; MacLennan and Simmonds 1992). A minimum value of $-65 \mathrm{~dB}$ was chosen in accordance with a previous acoustic study of glacier lanternfish (Torgersen and Kaartvedt 2001). Tracks of individual fish obtained by TT were also used for analysis of swimming behavior. Vertical swimming speeds of individuals were analyzed together with visual inspection of daily $24 \mathrm{~h}$ echograms in order to investigate any asynchronicity in the DVM pattern of the deeper living part of the population.

Both TT and echo integration were performed in the post processing program Sonar_5 pro version 5.9.9 (Balk and Lindem 2007).

The migration patterns below $250 \mathrm{~m}$ as assessed from the monthly echograms were compared with changes in concentration as assessed based on combining the measurements of $S_{\mathrm{v}}$ and TS. The maximum concentration of glacier lanternfish estimated below $250 \mathrm{~m}$ each day was assumed to reflect the total population below $250 \mathrm{~m}$. Increase and/or decrease in concentration, before and after the time of migration of a specific layer of glacier lanternfish, was used as a proxy for the relative proportion of glacier lanternfish with NoDVM, IDVM, and NDVM. The speed of migration by individuals in SL's was calculated by analyzing the distance of descent/ascent over time in SL's.

The continuous acoustic measurements were complemented by sampling during research cruises $1-4$ November 2007 with R/V "Haakon Mosby" (University of Bergen, IMR) and 3-7 October 2008 with R/V "Trygve Braarud" (University of Oslo). Results from the physical oceanography, zooplankton, and trawling studies from these field campaigns are used in the interpretations, but are presented elsewhere (Staby et al. 2011; Dypvik et al. 2012).

The behavioral patterns described in this study can with confidence be ascribed to glacier lanternfish. Previous studies covering spring and summer (Rasmussen and Giske 1994; Kaartvedt et al. unpublished), autumn (Bagøien et al. 2001; Kaartvedt et al. 2009), winter (Giske et al. 1990; Baliño and Aksnes 1993; Bagøien et al. 2001), and trawl data obtained during the present study (Staby et al. 2011; Dypvik et al. 2012), as well as subsequent studies (Kaartvedt et al. unpublished) have shown that glacier lanternfish are the main cause of backscattering deeper than $250 \mathrm{~m}$ in Masfjorden. Catches at these depths consist of specimens $>4.5 \mathrm{~cm}$, with a prevalence of individuals
$>6 \mathrm{~cm}$ below $300 \mathrm{~m}$ (Kaartvedt et al. 2009; Dypvik et al. 2012), that is adult individuals (Gjøsæter 1981). Pelagic shrimps are also common in the deep waters of Masfjorden (Kaartvedt et al. 1988, 2009) and may contribute somewhat to the backscatter. However, the SL's below $200 \mathrm{~m}$ in Masfjorden are pronounced also at $18 \mathrm{kHz}$ (Kaartvedt et al. 2008), signifying that the backscatter mainly consists of mesopelagic fish (Torgersen and Kaartvedt 2001; Love et al. 2004; Godø et al. 2009; Kloser et al. 2009). Furthermore, the average TS of the targets studied here (see "Results"; "Target strength and concentration estimates in deep water") is in accordance with previous studies of lanternfishes (Torgersen and Kaartvedt 2001; Yasuma et al. 2003; Kaartvedt et al. 2009), while shrimps have a TS about one magnitude weaker than that of glacier lanternfish (Benoit-Bird and Au 2001; Torgersen and Kaartvedt 2001).

\section{Results}

Main patterns in acoustic backscatter

In summer, there were four SL's performing NDVM to the surface at night, and one deep layer with no apparent diel behavior (Fig. 2). The upper of these layers ( 70-200 m) were ascribed to pearlside as they are found to dominate at these depths (the seasonal DVM patterns of pearlside are discussed in Staby et al. (2011) and will not be addressed in detail here). The two deeper layers $(>250 \mathrm{~m}$ during daytime) were ascribed to glacier lanternfish with NDVM and NoDVM, respectively. Zooming in on the deeper parts of the water column illustrates more clearly how organisms carrying out NDVM in summer descended to waters below $\sim 250 \mathrm{~m}$ at daytime, and ascended at night (Fig. 3).

In autumn, NDVM was still present above $\sim 200 \mathrm{~m}$, but was less noticeable below $\sim 200 \mathrm{~m}$ (Fig. 2). IDVM of acoustic targets ascribed to glacier lanternfish was now evident below the pearlside SL (Figs. 2, 3). An apparent non-migrating layer of glacier lanternfish occurred from $300 \mathrm{~m}$ to the bottom (Figs. 2, 3).

In winter, there were strong echoes of vertical migrating juvenile pearlside, and largely non-migrating adult pearlside in the upper $200 \mathrm{~m}$ (Fig. 2). The SL of individuals with IDVM (glacier lanternfish) was still apparent, although less pronounced than in autumn (Figs. 2, 3). The deepest non-migrating layer was now at its seasonal high in level of backscatter (Fig. 2).

In spring, several SL's with NDVM appeared between $\sim 100-210 \mathrm{~m}$ in daytime (March and April) and in the upper $\sim 100 \mathrm{~m}$ at night (Fig. 2). Glacier lanternfish likely contributed in the lower part of this layer. In May, individuals performing NDVM descended to $\sim 300 \mathrm{~m}$ in daytime, indicating a large portion of the glacier lanternfish 


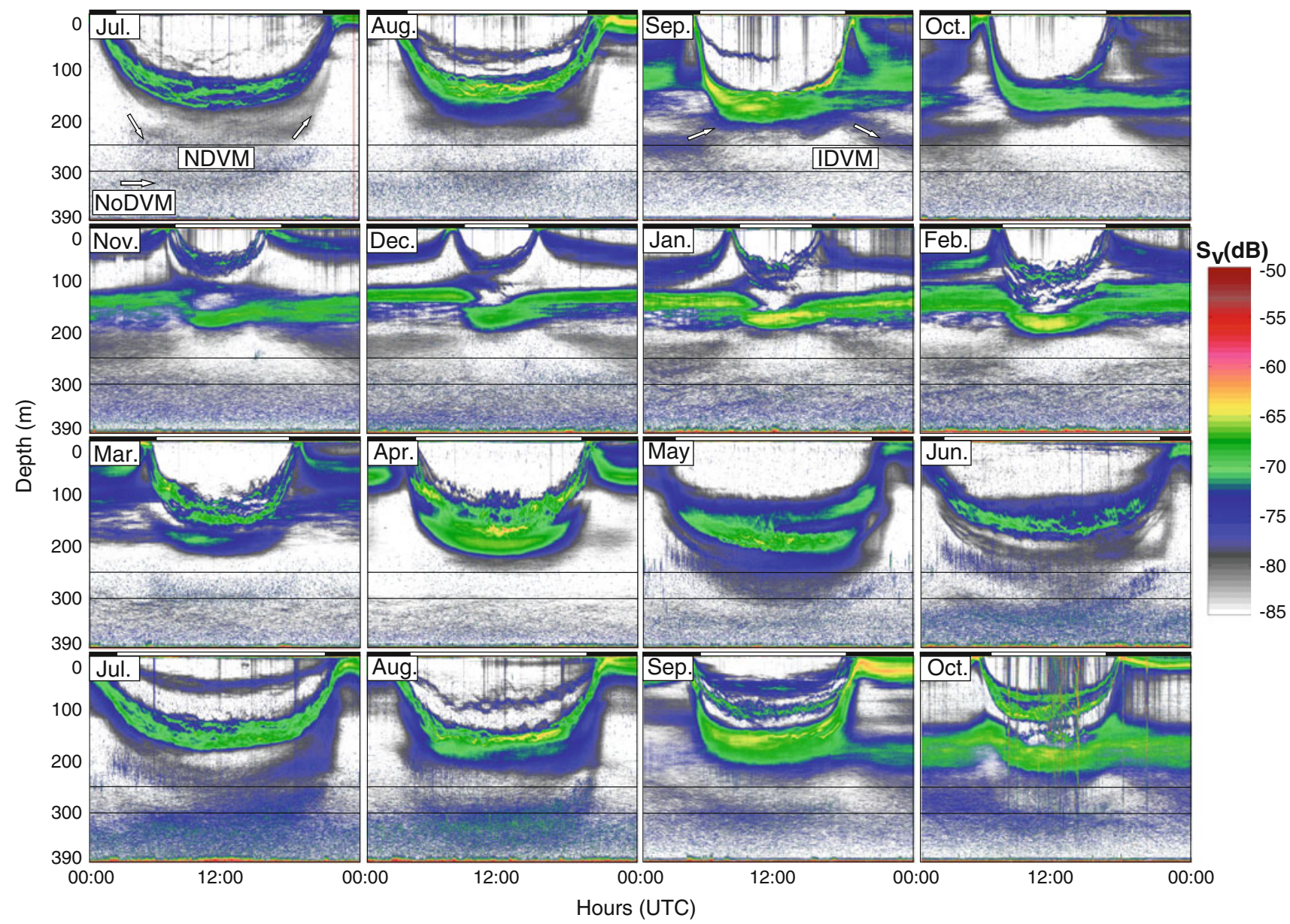

Fig. 2 Monthly average echograms from the $38 \mathrm{-kHz}$ echo sounder covering the water column $(\sim 0-390 \mathrm{~m})$ for $24 \mathrm{~h}$ in July $2007-$ October 2008. The dominant signal (green) and backscattering at shallower depth $(<200 \mathrm{~m})$ is dominated by pearlside, while glacier lanternfish dominate below $\sim 250 \mathrm{~m}$ (see Fig. 3 for clarification). The boxes indicate the intervals where the concentration (individuals $\mathrm{m}^{-3}$ ) of glacier lanternfish is calculated (see Fig. 7). Arrows in selected

population with this behavior (Figs. 2, 3). As on all other occasions, there was a SL with NoDVM below $\sim 300 \mathrm{~m}$ (glacier lanternfish), yet with a seasonal low in backscatter (Fig. 2).

Relative proportion of migration patterns

Estimated proportions with different DVM modes were calculated for each month based on the echograms and the echo integration from 250 to $390 \mathrm{~m}$ (Fig. 4). NDVM was performed by $\sim 25-55 \%$ of these fish in summer, while this behavior ceased in autumn and winter (Fig. 4). However, individuals performing NDVM re-appeared in early spring, and the proportion performing NDVM increased toward late spring (from $\sim 13 \%$ in March to $\sim 51 \%$ in May) (Fig. 4). The proportion performing IDVM increased from late summer ( $\sim 15 \%$ in August) to the beginning of echograms indicate the different behavioral patterns. The color scale refers to average volume backscattering $\left(S_{\mathrm{v}}\right)$ for each month; dark red illustrates the strongest, and white the weakest backscatter. The $S_{\mathrm{v}}$-thresholds are set to -50 and $-85 \mathrm{~dB}$ for the best possible illustration of the SL's. Black and white bars above echograms depict night and day separated by times for sunrise and sunset for the 15th each month. Time is given as UTC (local standard time $-1 \mathrm{~h}$ )

autumn (70\% in September 2007), then decreased throughout the winter (24\% in February 2008). In spring and the first part of summer, IDVM was not recorded (Fig. 4). NoDVM was suggested for $\sim 45-75 \%$ of the population at these depths during spring and summer, but this proportion decreased from summer to autumn ( $\sim 30-40 \%$ in September 2007 and 2008), before it increased toward the winter months (Fig. 4).

Individual behavior of glacier lanternfish

Visual inspection of $24 \mathrm{~h}$ echograms suggested little systematic vertical swimming among the NoDVM component in relation to time of day, as exemplified by 1 day each season in Fig. 5a-d. Fish at these depths commonly appeared to drift up and down in a consistent pattern suggesting internal wave motions (Fig. 5a-d). The limited 


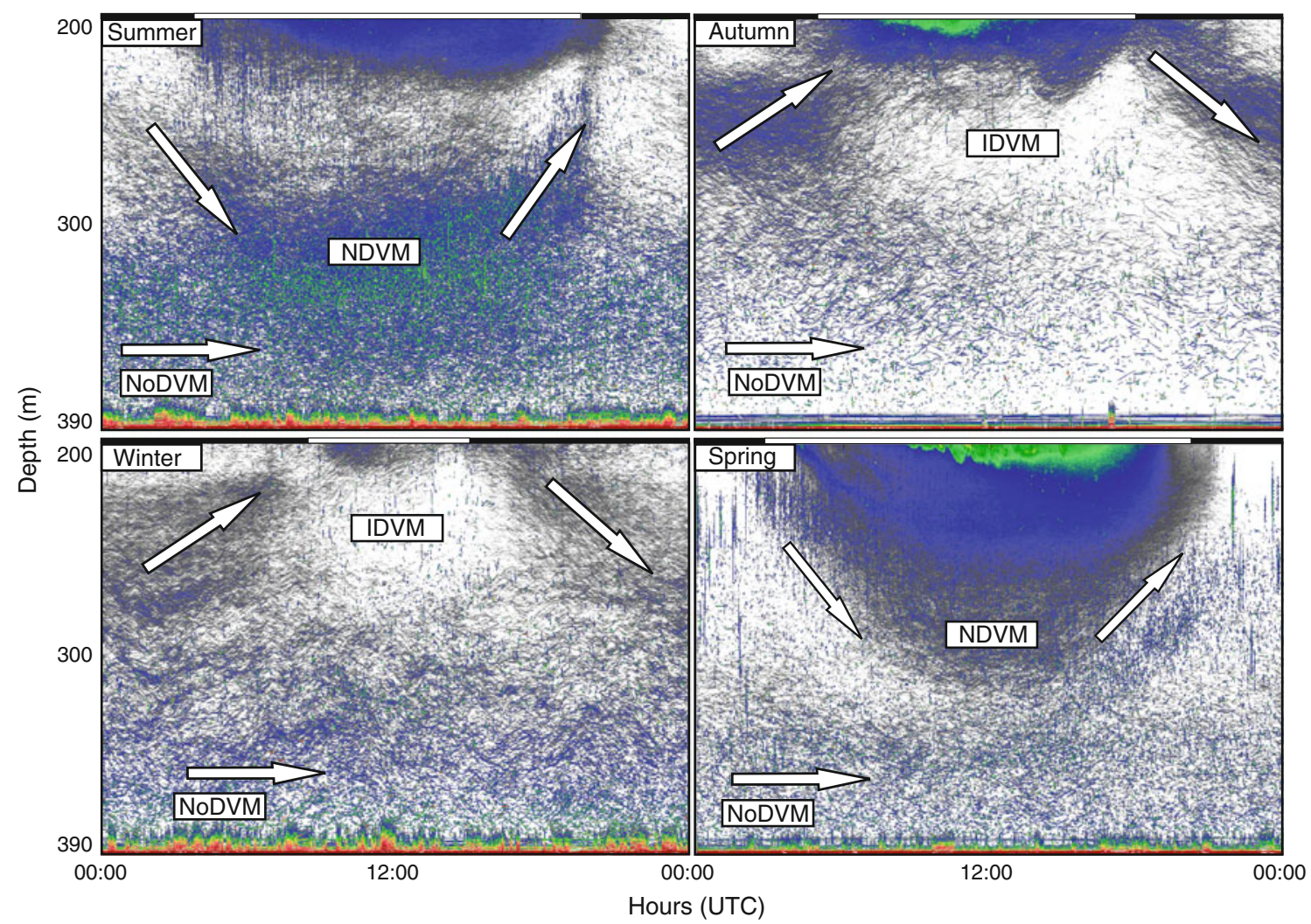

Fig. 3 Monthly average echograms from the $38 \mathrm{kHz}$ echo sounder (covering $24 \mathrm{~h}$ ) illustrating the deeper part of the water column ( 200-390 m) in summer (represented by August 2008), autumn (represented by September 2007), winter (represented by January 2008), and spring (represented by May 2008). Arrows in echograms indicate the different behavioral patterns; No diel vertical migration $(N o D V M)$, inverse diel vertical migration $(I D V M)$, and normal diel vertical migration (NDVM). The color scale refers to average volume backscattering $\left(S_{\mathrm{v}}\right)$ for each month; dark red illustrates the strongest, and white the weakest backscatter. Black and white bars above echograms depict night and day separated by times for sunrise and sunset for the 15th each month. Time is given as UTC (local standard time $-1 \mathrm{~h}$ )

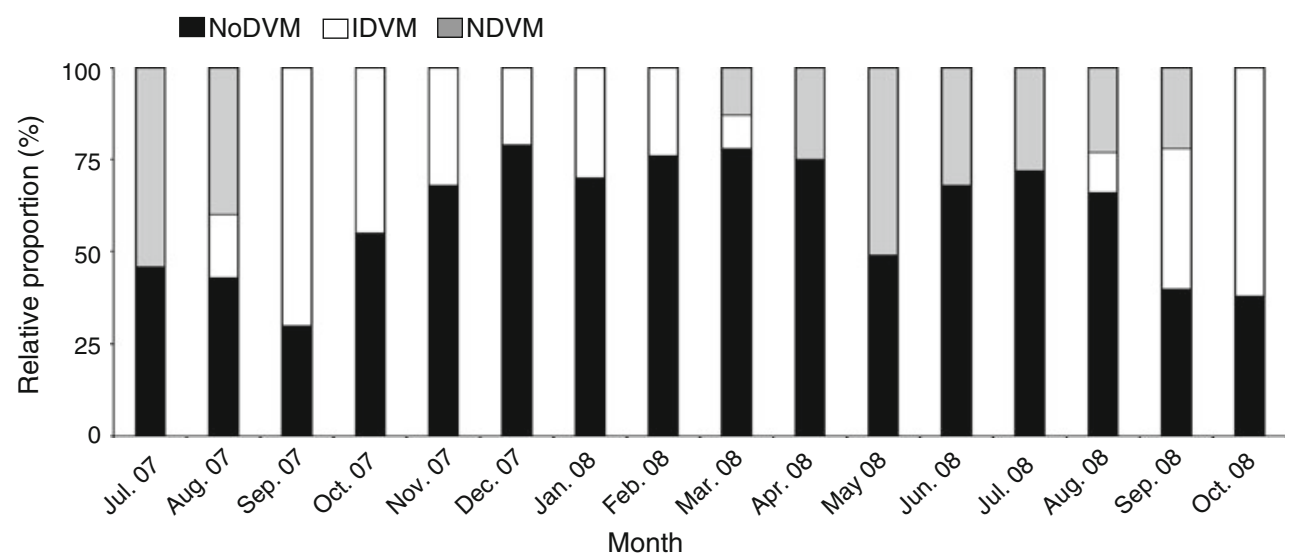

Fig. 4 The relative frequency of the population of glacier lanternfish (found below $250 \mathrm{~m}$ during daytime) with different DVM behaviors from July 2007-October 2008. No diel vertical migration (NoDVM),

vertical movement was reflected in the results from the year-round TT. Of more than 200,000 tracks retrieved by $\mathrm{TT}, \sim 85 \%$ revealed vertical relocation speed $<0.4 \mathrm{~cm} / \mathrm{s}$. However, intermittent vertical swimming was recorded in inverse diel vertical migration (IDVM), and normal diel vertical migration $(N D V M)$ are illustrated by black, white, and gray colors, respectively

which individuals ascended or descended in a step-wise pattern (Fig. 5e-h). The maximum vertical swimming speed detected was $\sim 18.4 \mathrm{~cm} / \mathrm{s}$. In comparison, the approximately ascending and descending speeds of the 
Fig. 5 a-d 24-h Echograms from the bottom-mounted $38 \mathrm{kHz}$ echo sounder on 8 August 2008 (a), 18 October 2007 (b), 2 February (c), and 12 March 2008 (d). The echograms are zoomed in at $\sim 300-390 \mathrm{~m}$. The outlined boxes are presented in higher resolution in (e-h). The color scale refers to average volume backscattering $\left(S_{\mathrm{v}}\right)$; dark red illustrates the strongest, and white the weakest backscatter. Black and white bars above echograms depict night and day separated by times for sunrise and sunset. Time is given as UTC (local standard time $-1 \mathrm{~h}$ )

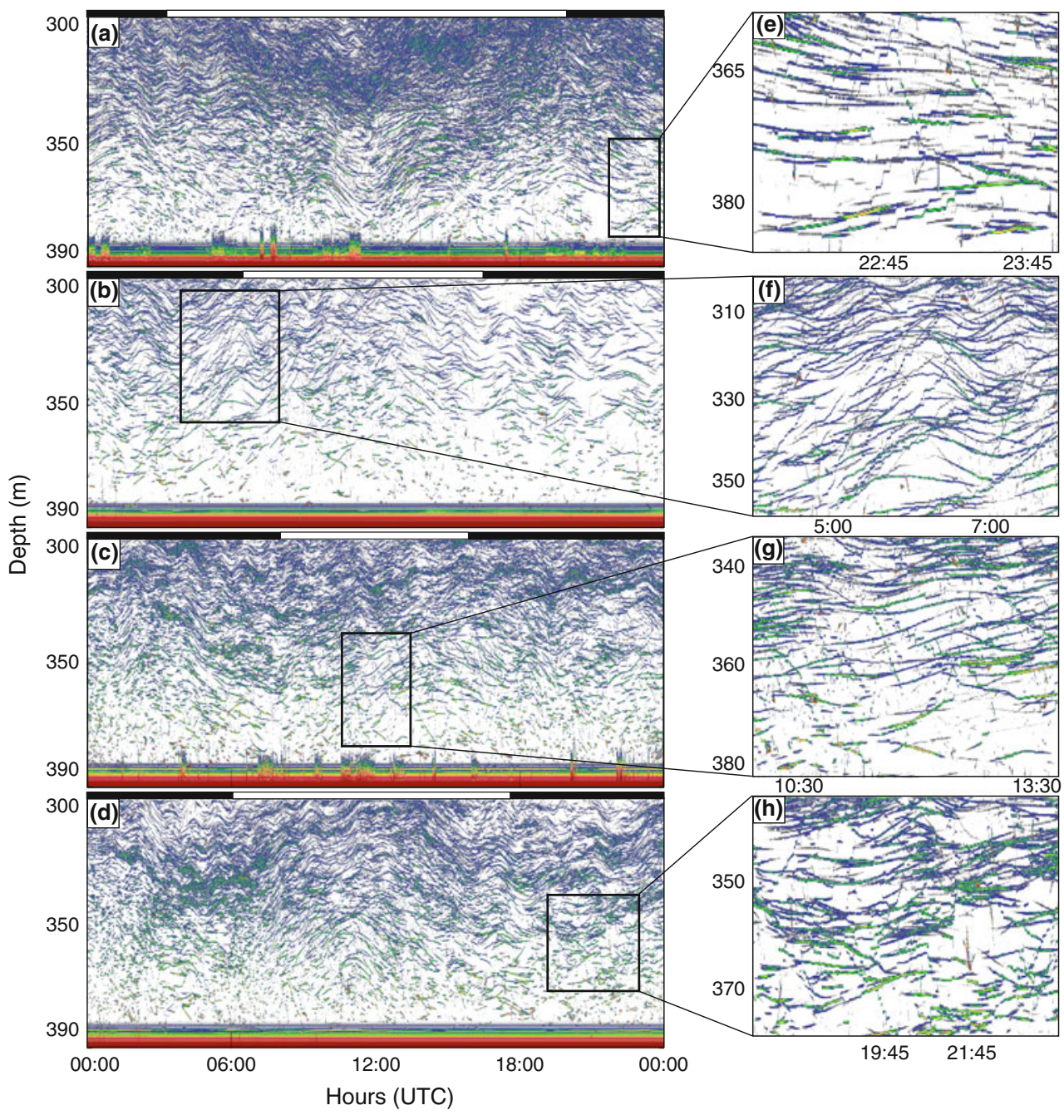

migrating layers were $3-4 \mathrm{~cm} / \mathrm{s}$ for the NDVM layer and $0.5-0.8 \mathrm{~cm} / \mathrm{s}$ for the IDVM layer. In addition to such marked vertical relocations, seemingly passively drifting fishes once in a while slightly adjusted their vertical distribution, subsequently taking up their apparent torpid behavior.

Target strength and concentration estimates in deep water

The average TS $(\mathrm{dB})$ of glacier lanternfish as measured between $\sim 340$ and $380 \mathrm{~m}$ were always in the range of approximately -57.5 to $-59.5 \mathrm{~dB}$. Within this limited range, the TS distribution of glacier lanternfish showed two peaks (in both summers) and decreased from the autumn to spring (Fig. 6).

The TS values were used in assessing the numerical densities of glacier lanternfish. The concentration of fish was usually in the range of $0.005-0.015$ individuals $\mathrm{m}^{-3}$ (Fig. 7a, b). However, the maximum density, just below 0.02 individuals $\mathrm{m}^{-3}$, was recorded in July 2008 in the

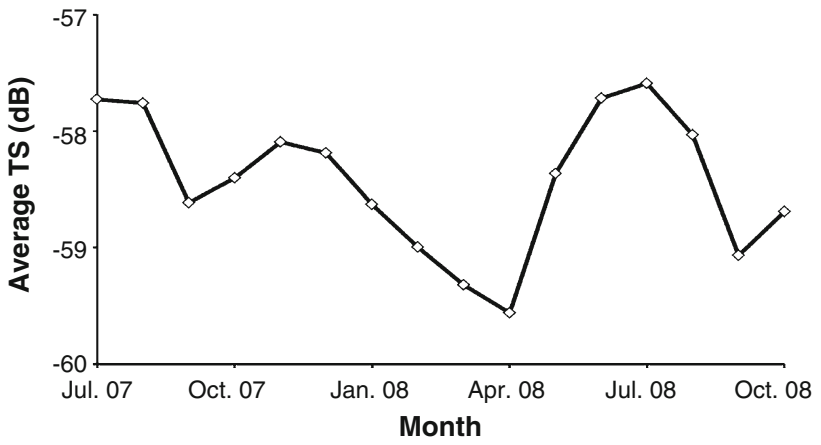

Fig. 6 Average TS (dB) of glacier lanternfish (total $n=209,768$ ) calculated from $\sim 340$ to $380 \mathrm{~m}$ for each month throughout the study period (July 2007-October 2008)

deepest interval (300-390 m), and in October 2008 in the shallower interval (250-300 m) (Fig. 7a, b).

In spring and summer, when NDVM is the dominating mode of migration, the daytime concentration of the interval $\sim 250-300 \mathrm{~m}$ was higher than during night (Fig. 7a). Below $300 \mathrm{~m}$, where the NoDVM mode were 


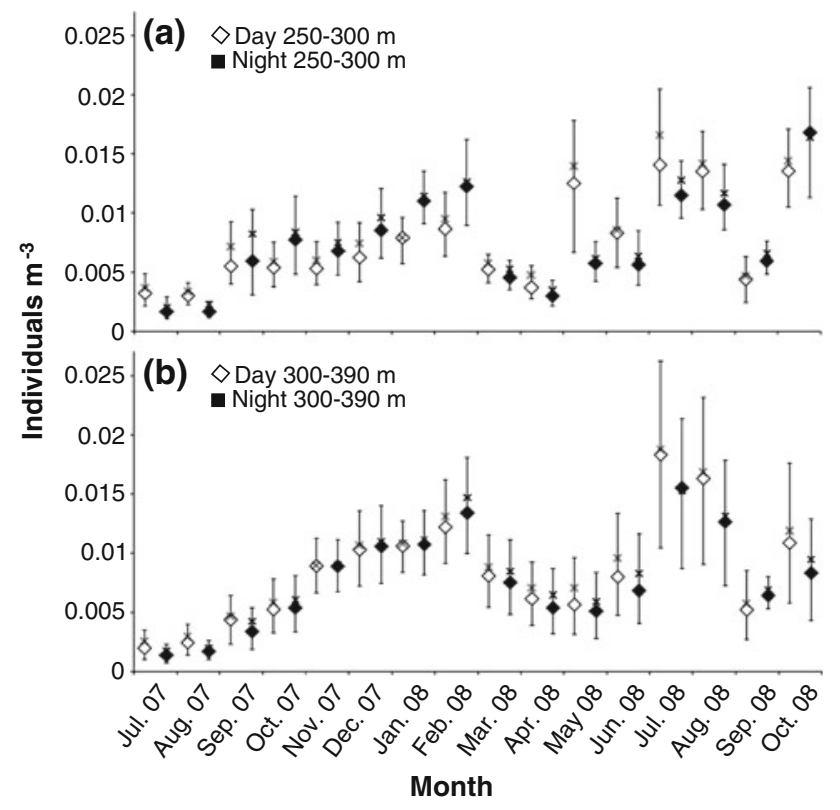

Fig. 7 a, b Estimated monthly average concentration (individuals per $\mathrm{m}^{3}$ ) of glacier lanternfish during day and night from (a) 250-300 m and (b) 300-390 m during July 2007-October 2008. The white and black squares indicate the median daytime and nighttime concentration estimates, respectively. The black lines illustrate the 1 st and 3rd Quartile, while the $X$ indicates the average estimated concentration

dominating, relatively little concentration fluctuations between day and night occurred, except for June-August 2008 (Fig. 7b) when the NDVM layers entered those depths at daytime (Fig. 2). In the months where IDVM were the dominating mode of migration (i.e. September-February), the concentration of glacier lanternfish decreased during daytime in the interval $\sim 250-300 \mathrm{~m}$ (Fig. 7a), as the inverse vertical migrators that were distributed from $\sim 220$ to $300 \mathrm{~m}$ during nighttime ascended to mid-waters (in the lower part of the strong SL between $\sim 150-220 \mathrm{~m}$ ) during the day (Figs. 2, 3).

\section{Discussion}

The 16-month acoustic data series revealed three different diel behavioral modes of glacier lanternfish. In NDVM, individuals ascend toward the surface at night and descend back to deeper waters in the morning. In IDVM, individuals ascend toward mid-waters at daytime, before descending at night. In NoDVM, individuals stay deeper than $\sim 300 \mathrm{~m}$ all day. A clear seasonal pattern, with NDVM prevailing during spring and summer, and IDVM prevailing during autumn and winter, was also apparent. All through the year, NoDVM occurred in the water column deeper than $\sim 300 \mathrm{~m}$. This diversity in diel behavior of glacier lanternfish has previously been observed during autumn in Masfjorden by Kaartvedt et al. (2009), Dypvik et al. (2012), but this is the first assessment of the yearly cycle. Note, however, that while the acoustic results unveil the main patterns in diel behavior for the part of the population below $\sim 200 \mathrm{~m}$, they do not provide the entire picture for the whole population. Only IDVM was recorded acoustically in October and November, yet trawl catches documented some NDVM (Kaartvedt et al. 2009; Dypvik et al. 2012). Also previous studies have documented NDVM of glacier lanternfish in fall and winter (Kaartvedt et al. 1988; Giske et al. 1990; Bagøien et al. 2001). Some shallower-living glacier lanternfish intermingle with, and thus become inseparable in the acoustic signatures of the SL dominated by adult pearlside (Torgersen and Kaartvedt 2001). Shallower-living glacier lanternfish are mostly smaller (Dypvik et al. 2012) and might be too small to be properly detected at $38 \mathrm{kHz}$. The largely consistency in TS values in deep water underlines that we likely have addressed the adult population throughout this study period. The slight apparent seasonal variation in TS does not seem to correlate with behavioral changes.

During spring and summer, glacier lanternfish performed NDVM toward the surface at night. During this time of year, the concentration of zooplankton peaks in the surface layers, and significantly lowers in the deeper waters (Atkinson and Peck 1988; Rasmussen and Giske 1994; Richter 1994). NDVM among lanternfishes is usually related to avoidance of visual predators in bright surface waters at daytime and subsequent feeding on zooplankton in the surface layers at night (Holton 1969; Dalpadado and Gjøsæter 1987; Kinzer et al. 1993). The pay-off from NDVM will decrease as surface plankton becomes less abundant throughout fall and winter, while at the same time, seasonally migrating copepods return to depth (Speirs et al. 2006; Broms and Melle 2007). This expectedly makes NDVM behavior less profitable. However, small individuals with less energy reserves, larger motivation, or less capability for feeding in deep water may continue to migrate toward the surface at night (Giske and Aksnes 1992), while larger fish may opt for other strategies such as staying in deeper waters feeding on overwintering calanoid copepods. In accordance with this, mainly 2 -year or older glacier lanternfish are distributed deeper than $\sim 250 \mathrm{~m}$, while smaller individuals are distributed in shallower waters, during autumn (Dypvik et al. 2012). Similar sizedependent depth distribution has also been observed in other studies of lanternfishes (Willis and Pearcy 1980; Gartner et al. 1987; Auster et al. 1992).

IDVM became apparent in August and was recorded until March. In winter, the bulk of zooplankton biomass is distributed in mid-waters (Giske et al. 1990; Baliño and Aksnes 1993; Bagøien et al. 2001). Dypvik et al. (2012) showed that inversely migrating glacier lanternfish were foraging on overwintering Calanus in mid-waters during 
the day. Other studies have shown that Calanus is an important part of the glacier lanternfish diet during fall and winter (Gjøsæter 1973; Baliño and Aksnes 1993). The seasonal occurrence of IDVM seems to harmonize well with the overwintering period for Calanus finmarchicus (Bagøien et al. 2001; Speirs et al. 2006), in both the timing of initiation of this behavior, and its termination in spring (Heath 1999; Astthorsson and Gislason 2003; Speirs et al. 2006; Broms and Melle 2007). By staying in deeper waters performing IDVM, glacier lanternfish may optimize their energy budget and reduce the predation risk (Dypvik et al. 2012). In addition, light decreases rapidly with depth in seawater (Sørnes and Aksnes 2006; Aksnes et al. 2009). A lanternfish swimming toward shallower waters, while still staying below $\sim 200 \mathrm{~m}$, will thus experience an increase of light in the surroundings, which would favor visual feeding by the low-light adapted lanternfish (Warrant and Locket 2004). Thus, it seems likely that individuals with IDVM ascend toward the overwintering layer of Calanus at daytime to feed at favored light levels, sinking back to deeper layers at night. However, the proportion of the population with IDVM decreases through the winter, which may reflect the reduced concentration of Calanus from autumn through winter (Bagøien et al. 2001).

Individuals of glacier lanternfish with NoDVM occurred all year at depths greater than $\sim 300 \mathrm{~m}$. Dypvik et al. (2012) found that the individuals with NoDVM during autumn were the largest individuals of the glacier lanternfish population. Individuals of greatest size tend to have larger eyes and might be better adapted than smaller individuals to detect prey in low light (Warrant and Locket 2004). They are also better adapted for handling large prey such as krill and shrimps, which occur deep in the water column (Kaartvedt et al. 1988; Baliño and Aksnes 1993; Kaartvedt et al. 2009; Dypvik et al. 2012), and which represent a much higher dividend than copepods due to their much larger size (Falk-Petersen 1981; Tande 1982). We therefore suggest that individuals with NoDVM are able to feed in the restricted light levels of the deep waters.

The behavior of individuals in deep water $(>300 \mathrm{~m})$ suggested that the NoDVM group indeed largely consisted of non-migrating individuals, and that consistent backscatter in deep water is not a result of asynchronous migrations, but that the population rather splits into migrating and non-migrating individuals, as initially suggested by Pearcy et al. (1979). Nevertheless, single individuals were observed swimming upwards or downwards in a step-wise fashion, as also observed by Kaartvedt et al. (2008, 2009). Intermittent vertical relocations, ascent/ descent in a step-wise fashion, would help the fish scan different parts of the water column for prey. Fish may also use their lateral lines for tactile prey detection in darkness (Janssen et al. 1999), and such behavior would be in accordance with both visual (O'Brien et al. 1990) and tactile (Janssen 1997; Janssen et al. 1999; Ryer and Olla 1999) search for prey. There was no evident relation with vertical swimming to time of day. However, the example from October (Fig. 5b) suggests a prominence of ascent at day, so we cannot reject the possibility that some of these deep-living individuals took part in IDVM at that time. Yet, most step-wise movements seemed to represent infrequent re-locations within the layer.

A wide variety of lanternfishes are capable of feeding at depths greater than several hundreds of meters (Pearcy et al. 1979; Roe and Badcock 1984; Sameoto 1988), and NoDVM has previously been observed among several species of lanternfish (Pearcy et al. 1979; Gartner et al. 1987; Collins et al. 2008). IDVM among lanternfishes has not been recorded from other localities. However, different species of Calanus occur in different geographic regions and, as well as other genera, perform seasonal vertical migration, overwintering in deeper water (Atkinson and Peck 1988; Richter 1995; Peterson 1998; Broms and Melle 2007). We therefore hypothesize that IDVM and NoDVM are widespread behaviors in areas where concentrations of potential prey are distributed in deeper waters, and that similar plasticity in DVM behavior as observed for glacier lanternfish in Masfjorden might occur in other populations of lanternfishes in areas with seasonally migrating zooplankton, such as overwintering calanoid copepods. Longterm acoustic measurements might be used to reveal such DVM plasticity in other areas, information that could be used to gain knowledge about interactions between lanternfishes, their prey and predators, as well as lanternfishes contribution to the vertical flux of organic matter. The vertical distribution and diel vertical migration of lanternfishes can affect such interactions and processes, making it imperative to further reveal these patterns.

Acknowledgments We would like to thank Thor A. Klevjer for help during the long-term acoustic study and data processing, Arved Staby for maintenance of the long-term acoustic set-up, and Dag L. Aksnes for feedback and ideas to the manuscript.

Open Access This article is distributed under the terms of the Creative Commons Attribution License which permits any use, distribution, and reproduction in any medium, provided the original author(s) and the source are credited.

\section{References}

Aksnes DL, Nejstgaard J, Sædberg E, Sørnes T (2004) Optical control of fish and zooplankton populations. Limnol Oceanogr 49:233238

Aksnes DL, Dupont N, Staby A, Fiksen Ø, Kaartvedt S, Aure J (2009) Coastal water darkening and implications for mesopelagic regime shifts in Norwegian fjords. Mar Ecol Prog Ser 387:39-49 
Albikovskaya LK (1988) Some aspects of the biology and distribution of Glacier Lanternfish (Benthosema glaciale) over the slopes of Flemish Cap and Eastern Grand Bank. NAFO Sci Count Stud $12: 37-42$

Astthorsson OS, Gislason A (2003) Seasonal variations in abundance, development and vertical distribution of Calanus finmarchicus, Calanus hyperboreus ans Calanus glacialis in the East Icelandic Current. J Plankton Res 25:843-854

Atkinson A, Peck JM (1988) A summer-winter comparison of zooplankton in the oceanic area around South Georgia. Polar Biol 8:463-473

Auster PJ, Griswold CA, Youngbluth MJ, Bailey TG (1992) Aggregations of myctophid fishes with other pelagic fauna. Environ Biol Fishes 35:133-139

Bagøien E, Kaartvedt S, Aksnes DL, Eiane K (2001) Vertical distribution and mortality of overwintering Calanus. Limnol Oceanogr 46:1494-1510

Bailey KM (1989) Interaction between the vertical distribution of juvenile walleye pollock Theragra chalcogramma in the Bering Sea, and cannibalism. Mar Ecol Prog Ser 53:205-213

Baliño BM, Aksnes DL (1993) Winter distribution and migration of the sound-scattering layers, zooplankton and micronekton in Masfjorden, western Norway. Mar Ecol Prog Ser 102:35-50

Balk H, Lindem T (2007) Sonar 4 \& Sonar 5_Pro Post processing systems. Operator manual 5.9.7. Lindem Data Acquisition, University of Oslo, Norway

Bennett WA, Kimmerer WJ, Burau JR (2002) Plasticity in vertical migration by native and exotic estuarine fishes in a dynamic lowsalinity zone. Limnol Oceanogr 47:1496-1507

Benoit-Bird KJ, Au WWL (2001) Target strength measurements of Hawaiian mesopelagic boundary community animals. J Acoust Soc Am 110:812-819

Brierley AS, Saunders RA, Bone DG, Murphy EJ, Enderlein P, Conti SG, Demer DA (2006) Use of moored acoustic instruments to measure short-term variability in abundance of Antarctic krill. Limnol Oceanogr Met 4:18-29

Broms C, Melle W (2007) Seasonal development of Calanus finmarchicus in relation to phytoplankton bloom dynamics in the Norwegian Sea. Deep Sea Res Part 2(54):2760-2775

Busch S, Mehner T (2012) Size-dependent patterns of diel vertical migration: smaller fish may benefit from faster ascent. Behav Ecol 23:210-217

Cailliet GM, Ebeling AW (1990) The vertical distribution and feeding habits of two common midwater fishes (Leuroglossus stilbius and Stenobrachius leucosarus) off Santa Barbara. CalCOFI Report 31:106-122

Cherel Y, Fontaine C, Richard P, Labat JP (2010) Isotopic niches and trophic levels of myctophid fishes and their predators in the Southern Ocean. Limnol Oceanogr 55:324-332

Clark CW, Levy DA (1988) Diel vertical migrations by juvenile Sockeye Salmon and the Antipredation Window. Am Nat 131: 271-290

Cohen JH, Forward RB Jr (2009) Zooplankton diel vertical migrationa review of proximate control. Oceanogr Mar Biol 47:77-110

Collins M, Xavier J, Johnston N, North A, Enderlein P, Tarling G, Waluda C, Hawker E, Cunningham N (2008) Patterns in the distribution of myctophid fish in the northern Scotia Sea ecosystem. Polar Biol 31:837-851

Dalpadado P, Gjøsæter J (1987) Observations on mesopelagic fish from the Red Sea. Mar Biol 96:173-183

Dalpadado P, Gjøsæter J (1988) Feeding ecology of the laternfish Benthosema pterotum from the Indian Ocean. Mar Biol 99:555-567

Doksæter L, Olsen E, Nøttestad L, Fernö A (2008) Distribution and feeding ecology of dolphins along the Mid-Atlantic Ridge between Iceland and the Azores. Deep Sea Res 2 (Top Stud Oceanogr) 55:243-253
Doksæter L, Godø OR, Olsen E, Nøttestad L, Patel R (2009) Ecological studies of marine mammals using a seabed-mounted echosounder. ICES J Mar Sci 66:1029-1036

Dypvik E, Klevjer TA, Kaartvedt S (2012) Inverse vertical migration and feeding in glacier lanternfish (Benthosema glaciale). Mar Biol 159:443-453

FalkPetersen S (1981) Ecological investigations on the zooplankton community of Balsfjorden, Northern Norway: seasonal changes in body weight and the main biochemical composition of Thysanoessa inermis (Krøyer), Thysanoessa raschii (M. Sars), and Meganyctiphanes norvegica (M. Sars) in relation to environmental factors. J Exp Mar Biol Ecol 49:103-120

Foote KG (1980) Importance of the swimbladder in acoustic scattering by fish: a comparison of gadoid and mackerel target strengths. J Acoust Soc Am 67:2084-2089

Gartner JV Jr, Hopkins TL, Baird RC, Milliken DK (1987) The lanternfishes (Pisces: Myctophidae) of the eastern Gulf of Mexico. Fish Bull 85:81-98

Giske J, Aksnes DL (1992) Ontogeny, season and trade-offs: vertical distribution of the mesopelagic Maurolicus muelleri. Sarsia 77: 253-261

Giske J, Aksnes DL, Balino BM, Kaartvedt S, Lie U, Nordeide JT, Salvanes AGV, Wakili SM, Aadnesen A (1990) Verticaldistribution and trophic interactions of zooplankton and fish in Masfjorden, Norway. Sarsia 75:65-81

Gjøsæter J (1973) Food of the myctophid fish, Benthosema glaciale (Reinhardt), from western Norway. Sarsia 52:53-58

Gjøsæter J (1981) Growth, production and reproduction of the myctophid fish Benthosema glaciale from western Norway and adjacent seas. Fisk Dir Skr Ser Hav Unders 17:79-108

Gjøsæter J, Kawaguchi K (1980) A review of the world resources of mesopelagic fish. FAO Fish Tech Pap 193:1-151

Godø OR, Patel R, Pedersen G (2009) Diel migration and swimbladder resonance of small fish: some implications for analyses of multifrequency echo data. ICES J Mar Sci 66:1143-1148

Halliday RG (1970) Growth and vertical distribution of the Glacier Lanternfish, Benthosema glaciale, in the Northwestern Atlantic. J Fish Res Bd Can 27:105-116

Hays GC, Proctor CA, John AWG, Warner AJ (1994) Interspecific differences in the diel vertical migration of marine copepods: the implications of size, color, and morphology. Limnol Oceanogr 39:1621-1629

Hays GC, Kennedy H, Frost BW (2001) Individual variability in diel vertical migration of a marine copepod: why some individuals remain at depth when other migrate. Limnol Oceanogr 46:2050 2054

Heath MR (1999) The ascent migration of Calanus finmarchicus from overwintering depths in the Faroe-Shetland Channel. Fish Oceanogr 8:84-99

Hedd A, Montevecchi WA, Davoren GK, Fifield DA (2009) Diets and distributions of Leach's storm-petrel (Oceanodroma leucorhoa) before and after an ecosystem shift in the Northwest Atlantic. Can J Zool Rev Can 87:787-801

Hernandez-Leon S, Franchy G, Moyano M, Menendez I, Schmoker C, Putzeys S (2010) Carbon sequestration and zooplankton lunar cycles: could we be missing a major component of the biological pump? Limnol Oceanogr 55:2503-2512

Holton AA (1969) Feeding behavior of a vertically migrating lanternfish. Pac Sci 23:325-331

Janssen J (1997) Comparison of response distance to prey via the lateral line in the ruffle and yellow perch. J Fish Biol 51:921-930

Janssen J, Sideleva V, Biga H (1999) Use of the lateral line for feeding in two Lake Baikal sculpins. J Fish Biol 54:404-416

Kaartvedt S (1996) Habitat preference during overwintering and timing of seasonal vertical migration of Calanus finmarchicus. Ophelia 44:145-156 
Kaartvedt S (2000) Life history of Calanus finmarchicus in the Norwegian Sea in relation to planktivorous fish. ICES J Mar Sci 57:1819-1824

Kaartvedt S, Aksnes DL, Aadnesen A (1988) Winter distribution of macroplankton and micronekton in Masfjorden, western Norway. Mar Ecol Prog Ser 45:45-55

Kaartvedt S, Torgersen T, Klevjer TA, Røstad A, Devine JA (2008) Behavior of individual mesopelagic fish in acoustic scattering layers of Norwegian fjords. Mar Ecol Prog Ser 360:201-209

Kaartvedt S, Røstad A, Klevjer TA, Staby A (2009) Use of bottommounted echo sounders in exploring behavior of mesopelagic fishes. Mar Ecol Prog Ser 395:109-118

Kinzer J, Schulz K (1985) Vertical distribution and feeding patterns of midwater fish in the central equatorial Atlantic. Mar Biol $85: 313-322$

Kinzer J, Böttger-Schnack R, Schulz K (1993) Aspects of horizontal distribution and diet of myctophid fish in the Arabian Sea with reference to the deep water oxygen deficiency. Deep Sea Res Part 2(40):783-800

Kloser RJ, Ryan TE, Young JW, Lewis ME (2009) Acoustic observations of micronekton fish on the scale of an ocean basin: potential and challenges. ICES J Mar Sci 66:998-1006

Kristoffersen JB, Salvanes AGV (2009) Distribution, growth, and population genetics of the glacier lanternfish (Benthosema glaciale) in Norwegian waters: contrasting patterns in fjords and the ocean. Mar Biol Res 5:596-604

Love RH, Fisher RA, Wilson MA, Nero RW (2004) Unusual swimbladder behavior of fish in the Cariaco Trench. Deep Sea Res 1 Oceanogr Res Pap 51:1-16

MacLennan DN, Simmonds EJ (1992) Fisheries acoustics, vol 5. Chapman \& Hall, London

Markaida U, Sosa-Nishizaki O (2003) Food and feeding habits of jumbo squid Dosidicus gigas (Cephalopoda: Ommastrephidae) from the Gulf of California, Mexico. J Mar Biol Assoc UK 83: $507-522$

Mehner T, Busch S, Helland IP, Emmrich M, Freyhof J (2010) Temperature-related nocturnal vertical segregation of coexisting coregonids. Ecol Freshw Fish 19:408-419

Neilson JD, Perry RI (1990) Diel vertical migrations of marine fishes-an obligate or facultative process. Adv Mar Biol 26:115-168

O'Brien WJ, Browman HI, Evans BI (1990) Search strategies of foraging animals. Am Sci 78:152-160

Pearcy WG, Lorz HV, Peterson W (1979) Comparison of the feedinghabits of migratory and non-migratory Stenobrachius-Leucopsarus (Myctophidae). Mar Biol 51:1-8

Pearre S (2003) Eat and run? The hunger/satiation hypothesis in vertical migration: history, evidence and consequences. Biol Rev 78:1-79

Peterson W (1998) Life cycle strategies of copepods in coastal upwelling zones. J Mar Syst 15:313-326

Pusch C, Hulley PA, Kock K-H (2004) Community structure and feeding ecology of mesopelagic fishes in the slope waters of King George Island (South Shetland Islands, Antarctica). Deep Sea Res Part 1(51):1685-1708

Radchenko VI (2007) Mesopelagic fish community supplies "biological pump". Raffles Bull Zool Suppl 14:265-271

Rasmussen OI, Giske J (1994) Life-history parameters and vertical distribution of Maurolicus muelleri in Masfjorden in summer. Mar Biol 120:649-664

Richter C (1994) Regional and seasonal variability in the vertical distribution of mesozooplankton in the Greenland Sea. Ber Polarforsch 154:1-87

Richter C (1995) Seasonal changes in the vertical distribution of mesozooplankton in the Greenland Sea Gyre $\left(75^{\circ} \mathrm{N}\right)$ : distribution strategies of calanoid copepods. ICES J Mar Sci 52:533-539
Ringelberg J (2010) Diel vertical migration of zooplankton in lakes and oceans: causal explanations and adaptive significances, vol 1. Springer, Dordrecht

Ringelberg J, Van Gool E (2003) On the combined analysis of proximate and ultimate aspects in diel vertical migration (DVM) research. Hydrobiologia 491:85-90

Roe HSJ, Badcock J (1984) The diel migrations and distributions within a mesopelagic community in the North East Atlantic. 5. Vertical migrations and feeding of fish. Prog Oceanogr 13: $389-424$

Rosland R, Giske J (1997) A dynamic model for the life history of Maurolicus muelleri, a pelagic planktivorous fish. Fish Oceanogr 6:19-34

Ryer CH, Olla BL (1999) Light induced changes in the prey consumption and behavior of two juvenile planktivorous fish. Mar Ecol Prog Ser 181:41-51

Sameoto DD (1988) Feeding of lantern fish Benthosema glaciale off the Nova Scotia Shelf. Mar Ecol Prog Ser 44:113-129

Sameoto D (1989) Feeding ecology of the lantern fish Benthosema glaciale in a subarctic region. Polar Biol 9:169-178

Shreeve RS, Collins MA, Tarling GA, Main CE, Ward P, Johnston NM (2009) Feeding ecology of myctophid fishes in the northern Scotia Sea. Mar Ecol Prog Ser 386:221-236

Sogard SM, Olla BL (1996) Food deprivation affects vertical distribution and activity of a marine fish in a thermal gradient: potential energy-conserving mechanisms. Mar Ecol Prog Ser 133:43-55

Sørnes TA, Aksnes DL (2006) Concurrent temporal patterns in light absorbance and fish abundance. Mar Ecol Prog Ser 325:181-186

Speirs DC, Gurney WSC, Heath MR, Horbelt W, Wood SN, de Cuevas BA (2006) Ocean-scale modelling of the distribution, abundance, and seasonal dynamics of the copepod Calanus finmarchicus. Mar Ecol Prog Ser 313:173-192

Staby A, Aksnes DL (2011) Follow the light—diurnal and seasonal variations in vertical distribution of the mesopelagic fish Maurolicus muelleri. Mar Ecol Prog Ser 422:265-273

Staby A, Rostad A, Kaartvedt S (2011) Long-term acoustical observations of the mesopelagic fish Maurolicus muelleri reveal novel and varied vertical migration patterns. Mar Ecol Prog Ser 441:241-255

Sutton TT, Hopkins TL (1996) Trophic ecology of the stomiid (Pisces: Stomiidae) fish assemblage of the eastern Gulf of mexico: strategies, selectivity and impact of a top mesopelagic predator. Mar Biol 127:179-192

Tande KS (1982) Ecological investigations on the zooplankton community of Balsfjorden, Northern Norway: generation cycles, and variations in body weight and body content of carbon and nitrogen related to overwintering and reproduction in the copepod Calanus finmarchicus (Gunnerus). J Exp Mar Biol Ecol 62:129-142

Torgersen T, Kaartvedt S (2001) In situ swimming behaviour of individual mesopelagic fish studied by split-beam echo target tracking. ICES J Mar Sci 58:346-354

Warrant EJ, Locket NA (2004) Vision in the deep sea. Biol Rev 79:671-712

Willis JM, Pearcy WG (1980) Spatial and temporal variations in the population size structure of three lanternfishes (Myctophidae) off Oregon, USA. Mar Biol 57:181-191

Wurtsbaugh WA, Neverman D (1988) Post-feeding thermotaxis and daily vertical migration in a larval fish. Nature 333:846-848

Yasuma H, Sawada K, Olishima T, Miyashita K, Aoki I (2003) Target strength of mesopelagic lanternfishes (family Myctophidae) based on swimbladder morphology. ICES J Mar Sci 60:584-591 